2-13-2007

\title{
Volcanic Eruptions at East Pacific Rise Near $9^{\circ} 50^{\prime} \mathrm{N}$
}

James P. Cowen

University of Hawaii, Manoa

Brooke Love

Western Washington University, USA, brooke.love@wwu.edu

Brian Glazier

University of Hawaii, Manoa

Daniel J. Fornari

Woods Hole Oceanographic Institution

Timothy M. (Timothy Mitchell) Shank

Woods Hole Oceanographic Institution

See next page for additional authors

Follow this and additional works at: https://cedar.wwu.edu/esci_facpubs

Part of the Environmental Sciences Commons, and the Oceanography Commons

\section{Recommended Citation}

Cowen, James P.; Love, Brooke; Glazier, Brian; Fornari, Daniel J.; Shank, Timothy M. (Timothy Mitchell); Soule, S. Adam; Treusch, Alexander; Pomranig, Kyle R.; Holmes, R. Chadwick; Tolstoy, Maya; and Baker, Edward T., "Volcanic Eruptions at East Pacific Rise Near 9 $50^{\prime} \mathrm{N}^{\prime \prime}$ (2007). Environmental Sciences Faculty and Staff Publications. 46.

https://cedar.wwu.edu/esci_facpubs/46 
Authors

James P. Cowen, Brooke Love, Brian Glazier, Daniel J. Fornari, Timothy M. (Timothy Mitchell) Shank, S.

Adam Soule, Alexander Treusch, Kyle R. Pomranig, R. Chadwick Holmes, Maya Tolstoy, and Edward T. Baker 
Eos, Vol. 88, No. 7, 13 February 2007

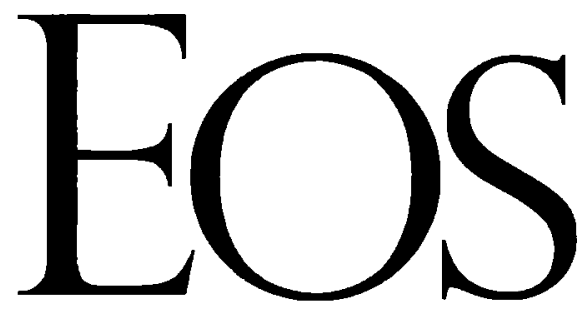

VOLUME 88 NUMBER 7

13 FEBRUARY 2007

\section{Volcanic Eruptions at East Pacific Rise Near 950'N}

\section{PAGES 81,83}

Evidence for recent volcanic eruptions along the fast spreading East Pacific Rise (EPR) crest near $9^{\circ} 50^{\prime} \mathrm{N}$ spanning about 4 to 5 months of activity was discovered in April and May 2006 as a result of studies related to the U.S. National Science Foundation's (NSF) Ridge2000 (R2K) program. In April, during routine recovery and redeployment of ocean-bottom seismometers (OBS) at the EPR R2K Integrated Study Site (ISS) near $9^{\circ} 50^{\prime} \mathrm{N}$, eight of 12 OBS could not be recovered [Tolstoy et al., 2006]. Anomalous turbidity and temperature structure in the water column along the ridge axis confirmed scientists' suspicions that the OBS were trapped by a new lava flow.

A resurgence in magmatism recently had been postulated, based on temporal changes observed over the past few years in hydrothermal vent fluid chemistry and temperatures [Von Damm et al., 2004] and increasing microseismicity [Tolstoy et al., 2006].

Within a week of the initial bottom-water surveys in late April, a rapid-event-response expedition on board the research vessel (R/V) New Horizon was mobilized. Conductivity-temperature-depth (CTD) and optical tow-yo (tows during which a package is alternately lowered and raised) surveys, hydrocasts, and towed digital imaging surveys at the EPR axis between $\sim 9^{\circ} 46^{\prime} \mathrm{N}$ and $9^{\circ} 57^{\prime} \mathrm{N}$ unequivocally confirmed the occurrence of recent extensive seafloor eruptions along more than 15 kilometers of the ridge axis and up to approximately 1 kilometer off axis, and they documented widespread vigorous hydrothermal venting and a notable absence of vent megafauna (Figure 1; http://www. ridge2000.org/science/tcs/epr06activity.html). Many of the hydrothermal vents studied over the past 15 years were disrupted.

This is the first repeat eruption documented at the same location along the mid-ocean ridge (MOR) crest; a prior eruption occurred in 1991-1992 [e.g., Haymon et al., 1993].

BY J. P.COWEN, D. J. FORNARI, T. M. SHANK, B. LOVE, B. Glazer,A. H. Treusch, R. C. Holmes, S.A.SOULE, E.T.BAKER, M.TOLSTOY, AND K. R. POMRANING

\section{Response Survey Strategy and Methods}

The primary objective of the rapid-response cruise was to determine whether or not a volcanic eruption recently had taken place, and if so, to assess its extent and its hydrothermal and biological impact. Ship-board equipment included a CTD with optical and electrochemical sensors and Niskin ${ }^{\mathrm{TM}}$ water sampling bottles [e.g., Baker et al., 1994] and a digital deep-sea camera with rock and water sampling capabilities (Woods Hole Oceanographic Institution TowCam [Fornari et al., 2003]). These instruments were easily mobilized and efficient tools to examine eruption effects on the water column, hydrothermal venting, and existing biological communities along the EPR axial summit trough (AST).

\section{Hydrothermal Plume Observations}

During seven days on station, three tow-yos were performed along the axis between $9^{\circ} 46.3^{\prime} \mathrm{N}$ and $9^{\circ} 54.2^{\prime} \mathrm{N}$, as well as three crossaxis tow-yos and two vertical casts (Figure 1). Along-axis tow-yos revealed particle plumes from $9^{\circ} 46.6^{\prime} \mathrm{N}$ to approximately $9^{\circ} 54.0^{\prime} \mathrm{N}$ (Figure $2 \mathrm{a}$ ). The most intense particle plumes were centered near $9^{\circ} 46.6^{\prime} \mathrm{N}$ and $9^{\circ} 51.5^{\prime} \mathrm{N}$ and also remained strong over the $9^{\circ} 50^{\prime} \mathrm{N}$ area, site of the most intense particle plume observed in late April. Cross-axis tow-yos revealed that deep currents were advecting the plumes primarily to the east during the cruise (Figure 2b).

Pronounced density inversion layers were found throughout the deepest 250 meters of water between $9^{\circ} 48.5^{\prime} \mathrm{N}$ and $9^{\circ} 50.5^{\prime} \mathrm{N}$ (Figure $2 \mathrm{a}$ ), consistent with vigorous hydrothermal venting but complicating the calculation of accurate temperature anomalies $(\Delta \theta)$, another conventional indicator of hydrothermal plume intensity [e.g., Baker et al., 1994]. Nevertheless, positive estimates of $\Delta \theta$ of approximately $0.01^{\circ} \mathrm{C}$ were observed in the bottommost 250 meters over the same region of the AST, with the highest $\Delta \theta\left(0.02\right.$ to $\left.>0.08^{\circ} \mathrm{C}\right)$ observed between $9^{\circ} 49.8^{\prime} \mathrm{N}$ and $9^{\circ} 50.8^{\prime} \mathrm{N}$, and near $9^{\circ} 47.4^{\prime} \mathrm{N}$. The strongest density inversions coincide with the largest $\Delta \theta$ [Tolstoy et al., 2006]. Baker et al. [1994] found similarly low temperature anomalies in the post-1991 EPR eruption plumes, and they attributed this to hydrographic masking of $\Delta \theta$ due to low salinity of the discharge fluids.

\section{Plume Chemistry}

Shipboard analyses indicated abnormally high levels of methane $\left(\mathrm{CH}_{4}\right)$ in the neutrally buoyant plumes to 350 nanomolar concentration (nM), with even higher levels in nearbottom-collected (TowCam) samples (to $937 \mathrm{nM}$ ), the latter possibly reflecting buoyant plumes over diffuse vents. Plume methane values are 4 to 100 times higher than normally found for 'stable' chronic-style plumes from hydrothermally active unsedimented ridges, and they are significantly greater than methane values (to $80 \mathrm{nM}$ ) measured over this portion of the EPR 6 months after the 1991 eruption [Mottl et al., 1995].

Stable carbon isotope values $\left(\delta^{13} \mathrm{C}\right)$ for replicate gas samples collected in May 2006 averaged $-20.34 \pm 6.87 \%$ o in the CTD-rosette water column samples, but were lower (averaging $-30.25 \pm 10.34 \%$ ) in near-bottom TowCam samples. Local ( $<2200$ meter depth) background $\delta^{13} \mathrm{C}$ values were $-35.9 \pm 8 \%$ (for $0.6 \pm 0.3 \mathrm{nM} \mathrm{CH}_{4}$ ). The variable $\delta^{13} \mathrm{C}$ values in the near-bottom, high- $\mathrm{CH}_{4}$ samples could indicate multiple methane source processes including microbial methanogenesis, the latter suggested by the prevalence of lowtemperature venting in TowCam photographs. The more ${ }^{13} \mathrm{C}$-enriched residual methane measured in most plume samples indicates active microbial methane oxidation throughout the lower water column along the AST.

Sulfide was detected in shipboard water column analyses as well as by in situ electrochemical analyzer (200 of 4059 scans, between $9^{\circ} 46.98^{\prime} \mathrm{N}$ and $\left.9^{\circ} 52.5^{\prime} \mathrm{N}\right)$. The distribution of detectable $(>0.1 \mathrm{nM})$ in situ hydrogen sulfide $\left(\mathrm{H}_{2} \mathrm{~S}\right)$ concentrations is consistent with that for the particle plumes and regions of vertical instability (Figure $2 \mathrm{a}$ ).

\section{Hydrothermal Plume Microbial Diversity}

Extensive expulsion of microbial biomass and products, including microorganisms apparently uniquely adapted to deep, hydrothermally active subsurface environments [e.g., Summit and Baross, 1998], have been recognized with past seafloor volcanic eruptions. Terminal restriction length polymorphism analysis of 16S rRNA genes 
amplified from biomass samples recovered with an in situ large-volume pump revealed differences in microbial diversity between the hydrothermal plume and ambient background.

These results were confirmed by restriction analyses of full-length 16S rDNA clones where one pattern dominated plume samples (39$56 \%$ of clones) while being nearly absent in the background (4\%). After analysis with a second restriction enzyme, clones with this pattern were divided into 15 different subpatterns. Further analysis is needed, but it is expected that the microbial community present in these hydrothermal plumes is dominated by one group of organisms. While the hydrothermal venting apparently influenced community diversity within the resulting hydrothermal plumes, further work is needed to identify the origin and geochemical impact of this change.

\section{Geological and Biological Observations From TowCam Surveys}

Along-axis TowCam surveys (Figure 1) acquired nearly continuous image coverage from $9^{\circ} 46^{\prime} \mathrm{N}$ to $9^{\circ} 57.6^{\prime} \mathrm{N}$ mostly within and sometimes just outside the AST. Hydrothermally active areas were identified by an approximately $0.5^{\circ}-2.0^{\circ} \mathrm{C}$ increase in potential temperature that frequently coincided with images of flocculent material in the water column or apparent microbial coatings on fresh lava surfaces (Figure 1).

Recently erupted lava was devoid of sediment but typically was dusted with white to brownish material (Figure 1), similar to that observed following the 1991 EPR eruption [e.g., Haymon et al., 1993]. Contacts between the new lava flow and older terrain were readily discernable in photographs (Figure 1). The new eruption covers about 15 kilometers along axis from $9^{\circ} 47.5^{\prime} \mathrm{N}$ to $9^{\circ} 55.7^{\prime} \mathrm{N}$ and between approximately one kilometer to only a few hundred meters east and west of the AST. The new lava flows (typically $<1$ meter thick) largely were erupted from fissures in the AST and overflowed the trough in many places, spilling out onto the EPR crestal plateau.

Further, the morphology of the new eruptions within the AST often is chaotic, consisting of sheet and hackly lava as well as flattened lobate forms suggesting high effusion rates. None of the preeruption hydrothermal vents within the AST floor in the $9^{\circ} 49^{\prime} \mathrm{N}-$ $50.3^{\prime} \mathrm{N}$ area was directly observed, but many of the older vent sites were coincident with active venting, apparent microbial production, and in a few cases, older sulfides engulfed by new lava. In one case, a self-recording, high-temperature fluid logger was observed on the south side of $\mathrm{M}$ vent chimney near $9^{\circ} 50.7^{\prime} \mathrm{N}$ on the east rim of the AST (Figure 1).

TowCam images revealed hydrothermal activity from $9^{\circ} 46.5^{\prime} \mathrm{N}$ to $9^{\circ} 54.9^{\prime} \mathrm{N}$, most concentrated between $9^{\circ} 49.7^{\prime} \mathrm{N}$ and $9^{\circ} 51.5^{\prime} \mathrm{N}$ (tens of meters of spacing between vents). To date, only diffuse venting has been pho-
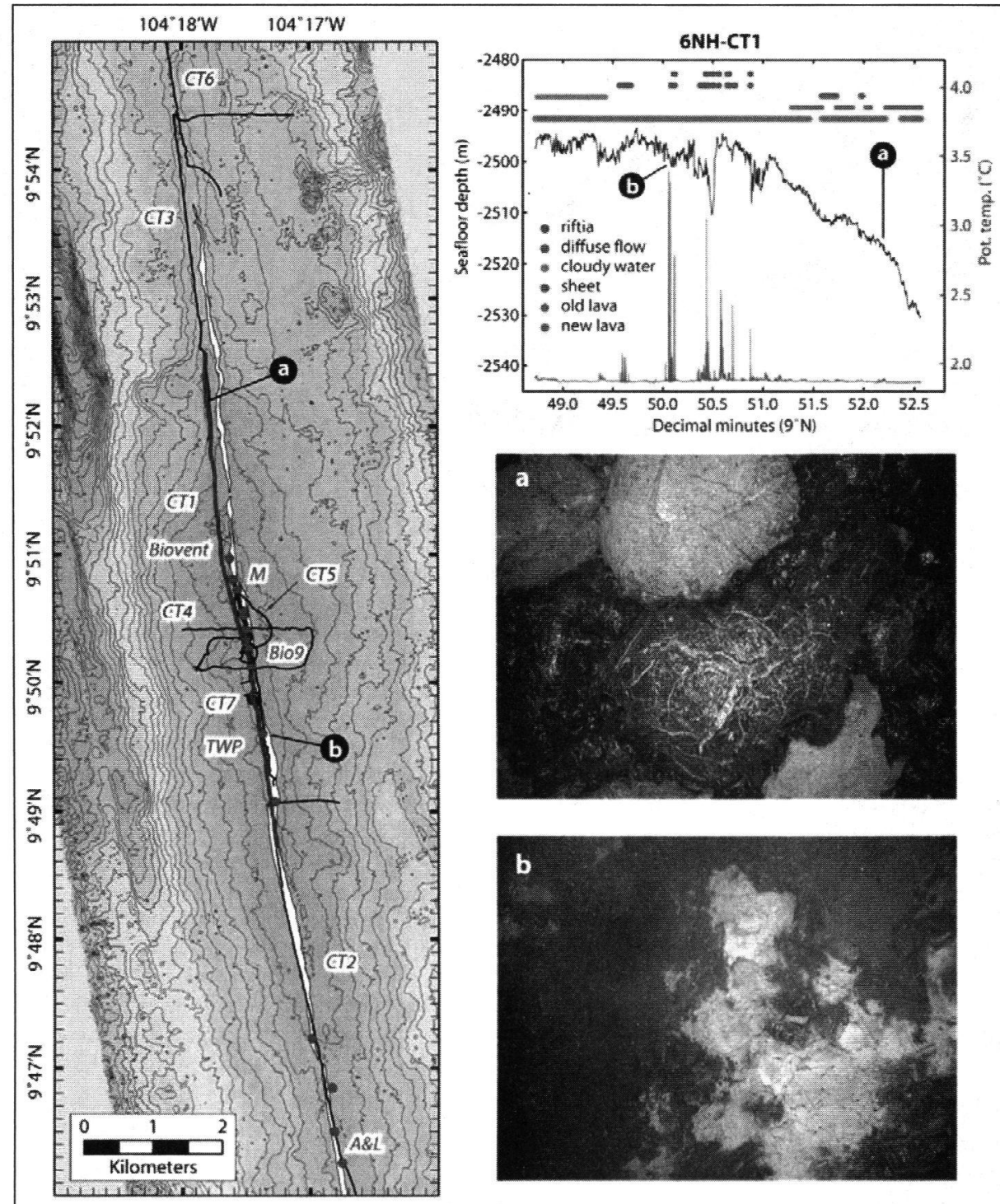

Fig. 1. (left) Location map of TowCam surveys over the new eruptions. Gray circles indicate positions of old high-temperature hydrothermal vents. (top right) Near-bottom seafloor profile compiled from depth and altitude data from TowCam 1 is shown with geological and biological observations keyed to shaded symbols. Potential temperature from TowCam is shown in gray below the profile. TowCam photographs, keyed to their location along the track, include (middle right) new pillow to lobate lava flow overlying older sediment covered pillows and (bottom right) diffuse hydrothermal venting through recently erupted lava covered with potential microbial material. Original color image appears at the back of this volume.

tographed, but water column tow-yos indicate the presence of high-temperature venting. Extensive white mats, presumed to be microbial material, existed in all areas of active venting. Snow-blower-type venting was observed in at least three locations. No sessile faunal colonization was observed in 'newly venting' areas. The only extant communities observed were tubeworm tubes (all apparently belonging to Riftia pachyptila) near $9^{\circ} 49.2^{\prime} \mathrm{N}$ and $9^{\circ} 50.5^{\prime} \mathrm{N}$. The similarities in the biological and volcanic features observed in May 2006 relative to observations following the 1991-1992 EPR eruption [e.g., Shank et al., 1998] suggest that one or more eruptions occurred at the EPR ISS over the previous 9 months

\section{Importance of 'Rapid-Event Responses'}

These results demonstrate that 'rapidevent response' to MOR eruptions can be quickly and efficiently mounted (i.e., in $<1$ week) to areas outside the northeast Pacific, and that these surveys can effectively document recent seafloor eruptions, identify transient posteruptive processes, and initiate longer-term studies. The data presented provide conclusive proof that new volcanic flows have been erupted at the EPR ISS, and that the near-bottom hydrographic and hydrothermal systems as well as extensive faunal communities have been significantly affected. These studies facilitated further response efforts, primarily in the form 
Eos, Vol. 88, No. 7, 13 February 2007

of an Alvin/Atlantis cruise (AT15-6) that took place from 18 June to 6 July 2006, within approximately 3 weeks of the completion of the New Horizon surveys.

\section{Acknowledgments}

We thank the scientific party, captain, and crew of R/V New Horizon, the marine operations personnel at SIO, L. Goad, R. Batiza, B. Haq, and A. Shor at NSF, and the Ridge2000 office for helping to mobilize this response cruise at such short notice, and colleagues on the R/V Knorr (D. Forsyth and A. Saal, co-Chief Scientists) and coinvestigators S. Giovannoni and K. Vergin (OSU) for making key preliminary data available. This work was supported by NSF awards OCE-0222069 (J.P.C.); OCE-0525863 (D.J.F); and OCE-0327261 (T.M.S.) and by the NASA Astrobiology Institute under Cooperative Agreement No.

NNA04CC08A. This is School of Ocean and Earth Science and Technology contribution 7018.

\section{References}

Baker, E.T., R.A. Feely, M.J. Mottl, F.J.Sansone, C. G. Wheat, J.A. Resing, and J. E. Lupton (1994), Hydrothermal plumes along the East Pacific Rise, $8^{\circ} 40^{\prime}$ to $11^{\circ} 50^{\prime} \mathrm{N}$ : Plume distribution and relationship to the apparent magmatic budget, Earth Planet. Sci. Lett., 128, 1-17.

Fornari, D. J., et al. (2003), A new deep-sea towed digital camera and multi-rock coring system, Eos Trans. $A G U, 84(8), 69,73$.

Haymon, R. M., et al. (1993), Volcanic eruption of the mid-ocean ridge along the East Pacific Rise crest at $9^{\circ} 45-52 ' \mathrm{~N}$ : Direct submersible observations of seafloor phenomena associated with an eruption event in April, 1991, Earth Planet. Sci. Lett., 119, 85-101.

Mottl, M. J., F. J.Sansone, C. G.Wheat, J.A. Resing, E.T. Baker, and J. E. Lupton (1995), Manganese and methane in hydrothermal plumes along the East Pacific Rise, $8^{\circ} 40^{\prime}$ to $11^{\circ} 50^{\prime} \mathrm{N}$, Geochim. Cosmochim. Acta, 59, 4147-4165.

Shank, T. M., D. J. Fornari, K. L.Von Damm, M. D. Lilley, R.M.Haymon, and R.A.Lutz (1998), Temporal and spatial patterns of biological community development at nascent deep-sea hydrothermal vents along the East Pacific Rise, Deep Sea Res., Part II, 45, 465-515.

Summit, M., and J. A. Baross (1998), Thermophilic subseafloor microorganisms from the 1996 North Gorda Ridge eruption, Deep Sea Res., 45, 2751-2766.

Tolstoy, M., et al. (2006), A seafloor spreading event captured by seismometers, Science, doi:10.1126/ science. 1133950 .

Von Damm, K. L. (2004), Evolution of the hydrothermal system at East Pacific Rise $9^{\circ} 50 ' \mathrm{~N}$ : Geochemi-

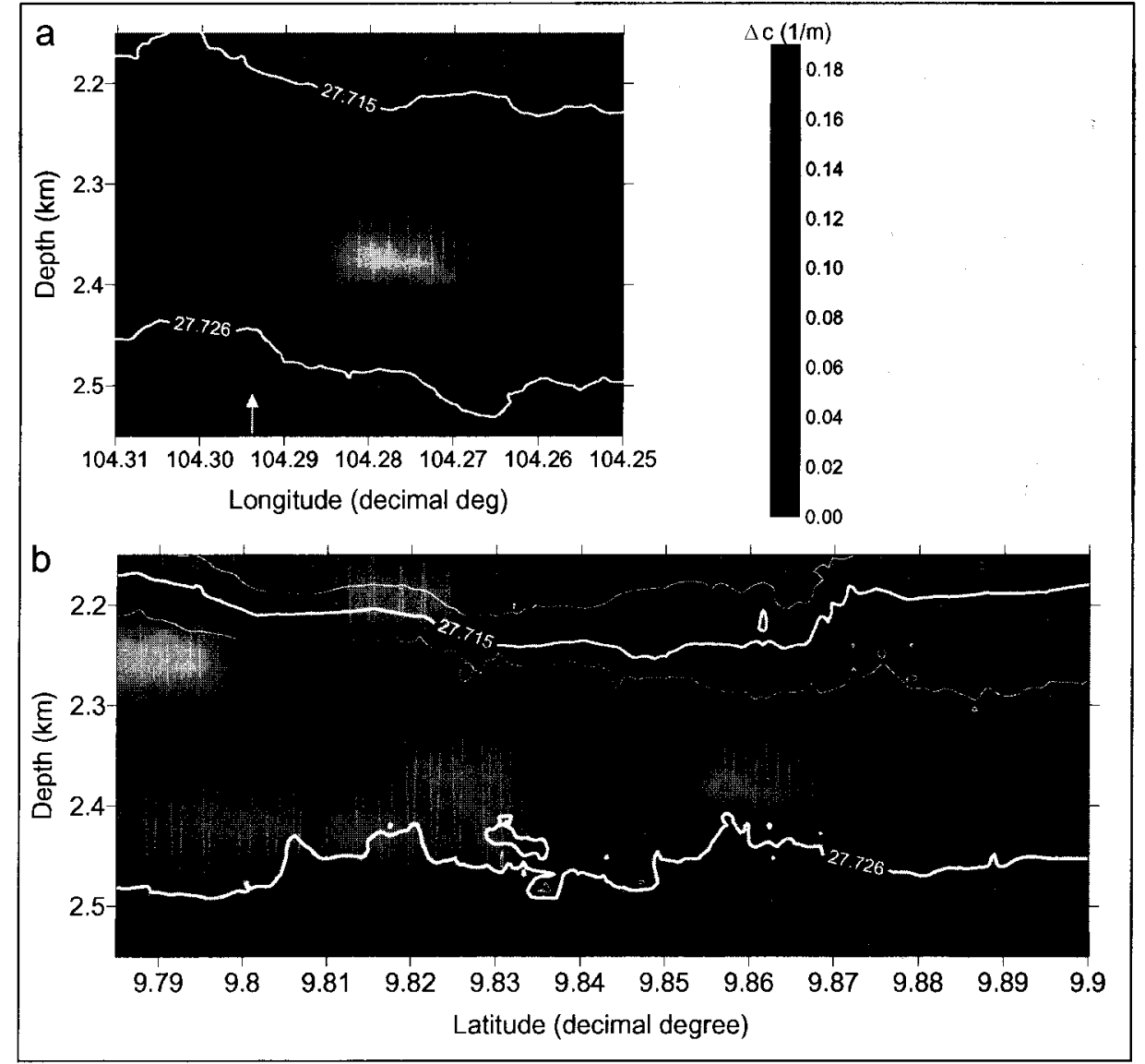

Fig. 2. Contour plots of light attenuation ( $\Delta c$;per meter) versus (a) depth and longitude for a cross-axis (CTD Tow 5) tow-yo and (b) depth and latitude for an along-axis tow-yo (ridge summit). Density (kilograms per cubic meter) contours (solid white curves) are superimposed over $\Delta c$; the deepestdensity line indicates localized areas of instability in the lower part of the water column.The dotted grey curve indicates the sawtoothed tow pattern of the instrument package (SeaBird SBE-911 CTD configured with SeaTech 347 light backscalter sensor; WetLabs CST493DR transmissometer; LISST Deep laser in situ scattering and transmission sensor (particle size distributions); ISEA electrochemical analyzer; and a rosette of 21 ten-liter SIO-built, Niskin-style sampling bottles). Original color image appears at the back of this volume.

cal evidence for changes in the upper oceanic crust, in Mid-Ocean Ridges: Hydrothermal Interactions Between the Lithosphere and Ocean, Geophys. Monogr.Ser, vol. 148, edited by C. German et al., pp. 285-304,AGU, Washington, D.C.

\section{Author Information}

James PCowen and Brian Glazer, University of Hawaii, Honolulu, and NASA Astrobiology Institute; E-mail: jcowen@soest.hawaii.edu; Daniel J. Fornari, Timothy M.Shank, and S.Adam Soule, Woods Hole
Oceanographic Institution, Woods Hole, Mass.; Brooke Love, University of Washington, Seattle; Alexander Treusch and Kyle R. Pomranig, Oregon State University, Corvallis; R. Chadwick Holmes and Maya Tolstoy, Lamont-Doherty Earth Observatory, Palisades, N.Y; Edward T. Baker, U.S. National Oceanic and Atmospheric Administration, Pacific Marine Environmental Laboratory, Seattle, Wash. 


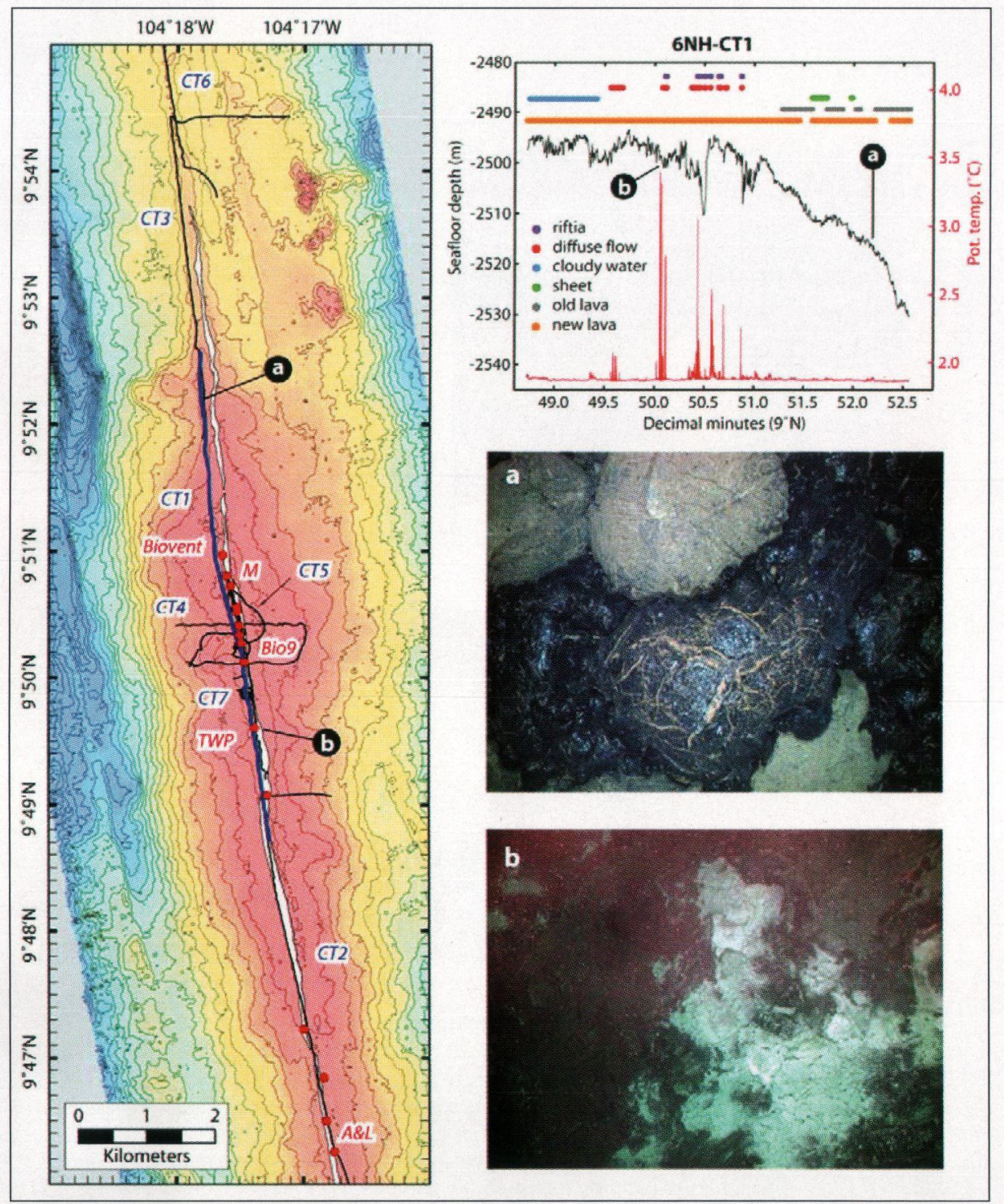

Fig. 1. (left) Location map of TowCam surveys over the new eruptions. Red circles indicate positions of old high-temperature hydrothermal vents. (top right) Near-bottom seafloor profile compiled from depth and altitude data from Tow Cam 1 is shown with geological and biological observations keyed to colored symbols. Potential temperature from Tow Cam is shown in red below the profile. TowCam photographs, keyed to their location along the track, include (middle right) new pillow to lobate lava flow overlying older sediment covered pillows and (bottom right) diffuse hydrothermal venting through recently erupted lava covered with potential microbial material. 


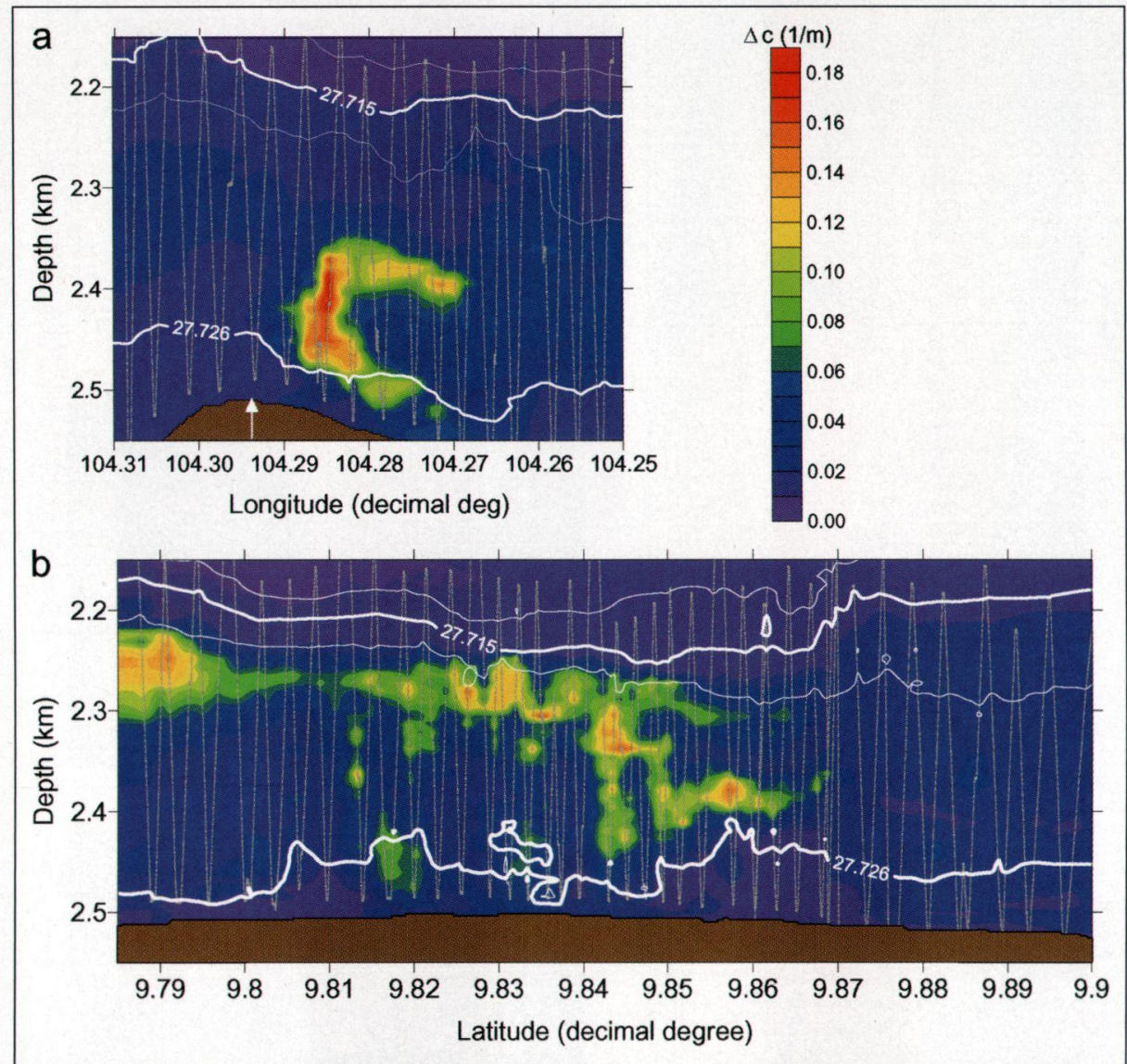

Fig. 2. Contour plots of light attenuation ( $\Delta c$;per meter) versus (a) depth and longitude for a cross-axis (CTD Tow 5) tow-yo and (b) depth and latitude for an along-axis tow-yo (ridge summit). Density (kilograms per cubic meter) contours (solid white curves) are superimposed over $\Delta c$; the deepestdensity line indicates localized areas of instability in the lower part of the water column.The dotted grey curve indicates the sawtoothed tow pattern of the instrument package (SeaBird SBE-911 CTD configured with SeaTech 347 light backscatter sensor; WetLabs CST493DR transmissometer; LISSTDeep laser in situ scattering and transmission sensor (particle size distributions); ISEA electrochemical analyzer; and a rosette of 21 ten-liter SIO-built, Niskin-style sampling bottles). 